\title{
Kristen etik mellem kompromis og radikalitet
}

\section{Om ansvarsetikken som en tredje vej inspireret af K.E. Løgstrup og Dietrich Bonhoeffer}

\author{
"Der er jo ikke kristendom til uden etik" \\ K.E. Løgstrup, Det nomtvistelige. ${ }^{1}$
}

\author{
Lektor, ph.d., dr. theol. \\ Ulrik Nissen
}

\begin{abstract}
K. E. Løgstrup's The Ethical Demand, first published in 1956, has proved to hold insights that give it continued resonance in Scandinavian theology and beyond. Among other things, its rejection of a Christian ethic continues to be debated. Such a critical stance towards Christian ethics can also be found in Dietrich Bonhoeffer. But in contrast to Løgstrup, he can still endorse a Christian discipleship and the call to bear witness to Christ. By bringing Løgstrup and Bonhoeffer into conversation it can be argued that an ethic of responsibility as a responsive concept can open up for a Christian ethic in a third position between compromise and radicalism.
\end{abstract}

Keywords: Løgstrup - Bonhoeffer - ethics - theological ethics - Christian ethics - radicalism - compromise - responsibility

\section{Introduktion}

I en dansk sammenhæng fortsætter diskussionen tilsyneladende ufortrødent om, hvorvidt der overhovedet er en kristen etik. ${ }^{2}$ Hvor diskussionen i mange andre lande har bevæget sig videre, og man er blevet

1. K.E. Løgstrup, Det uomtvistelige. Fem samtaler med Helmut Friis (Askov: Askov Højskoles Forlag 1984), 59.

2. Jeg anvender i det følgende betegnelsen "kristen" etik som synonym med "kristelig" etik. Derved forstår jeg en kritisk refleksion over de etiske implikationer af kristendommens grundlag, historie og praksis. "Teologisk" etik forstår jeg i denne sammenhæng som den kritiske refleksion knyttet til fagområdet "Etik og Religionsfilosofi" og dermed som den teologiske disciplin, der har dette som sin særlige opgave i samtale med andre teologiske discipliner og andre fagområder. Denne ganske korte bestemmelse yder naturligvis ikke spørgsmålet om forholdet mellem kristen 
mere optaget af teologisk at gå i dybden med nogle af de store etiske og samfundsmæssige spørgsmål, som hele tiden melder sig, synes der $i$ en dansk sammenhæng at være en inerti indlejret i selve grundlagsspørgsmålet om den kristne etiks berettigelse og udtryk. Nogle af disse spørgsmål har en teologisk karakter, da de tager fat på selve diskussionen om forholdet mellem troen og troens udtryk eller den mere klassisk lutherske diskussion om forholdet mellem lov og evangelium. Luthersk set kan det da også langt hen ad vejen give god mening at hævde, at fordringen isoleret set kan forstås alment, og at der derfor ikke er noget særligt kristeligt ved den som sådan. Det er den forståelse, vi møder hos en af de store aarhusteologer, K.E. Løgstrup, særligt i Den etiske fordring, som blev udgivet første gang i $1956 .{ }^{3}$ Denne bog har vist sig at rumme indsigter, der efterhånden har givet den status som en klassiker. Løgstrups hævdelse af fordringens alment humane karakter har ligheder med traditionen om den naturlige lov, som den også kan læses som en reformulering af. ${ }^{4}$ Tanken om, at den teologiske etik har en afgørende almen side, deles af denne artikels forfatter. Den almene side af den teologiske etik rummer noget helt afgørende om forholdet mellem Gud og menneske, forholdet mellem mennesker indbyrdes og forholdet mellem mennesker og natur, som vi ikke kan og ikke bør opgive. Det er vigtigt at fastholde. I anledning af 75 års jubilæet for teologi på Aarhus Universitet giver det derfor også god mening at tage fat på dette værk og reflektere over dets fortsatte betydning.

Når diskussionen om den kristne etik undertiden spidser til i en dansk sammenhæng, har det at gøre med spørgsmålet, om der også kan siges at være en mere specifik kristen etik. Med andre ord: kan vi hævde, at der er en kristen etik, som udtrykker noget særligt kendetegnende for det kristne liv eller den kristne tro? Her begynder vandene at skilles. Det er en teologisk uenighed, som er tæt forbundet med det grundlæggende spørgsmål, om troen kan siges at indebære en forvandling af det kristne menneske? Og om vi kan sætte ord på dele af denne forandring? Her kommer vi til et spørgsmål, hvor Løgstrup

og teologisk etik retfærdighed, men lige netop i diskussionen om Løgstrup kan det være væsentligt at sondre mellem de to.

3. Den etiske fordring (DEF) er siden den første udgivelse kommet i flere nye udgaver. Jeg holder mig i denne artikel til den seneste, K.E. Løgstrup, Den etiske fordring. (Aarhus: Forlaget Klim 2010). Jeg refererer derfor også til siderne i denne udgave, men anvender årstal for den oprindelige udgivelse. Jeg anvender i det følgende forkortelsen DEF, når værket ikke indgår i andre titler eller citater.

4. Se for eksempel Svend Andersen, Løgstrup (Frederiksberg: Forlaget ANIS 1995), 54f., 67f. og idem, "Efter loven - Den etiske fordring som luthersk etik", Livtag med den etiske fordring, red. David Bugge \& Peter Aaboe Sørensen (Aarhus: Forlaget Klim 2007), 65-80 (72, 78). 
ville svare nej. Det er denne afvisning af en kristelig etik, som vil blive genstand for en kritisk læsning i det følgende afsnit. Samtidigt rejser afvisningen også spørgsmålet, om vi kan undvære denne specifikke side? Mister vi ikke noget helt afgørende for en kristen etik, hvis vi ikke har denne side med?

Diskussionen af Løgstrup vil blive fulgt op af en kort redegørelse for udvalgte træk ved Dietrich Bonhoeffers etik, som netop placerer sig imellem en almen og specifik etik, eller som han formulerer det, mellem kompromis og radikalitet. Læsningen af Bonhoeffer vil kort drøfte hans forståelse af etik, herunder hans etikkritik, for herigennem at udfolde, hvordan han formår at fastholde tanken om en kristen etik. For Bonhoeffer er det afgørende, at den kristne etik er bestemt af det kristne menneskes forhold til Kristus, og at dette indebærer et kald til at bære vidnesbyrd om Kristus. Det medfører for Bonhoeffer, at han samtidigt med den almene bestemmelse af etikken fastholder en specifik bestemmelse.

Diskussionen af Løgstrup og Bonhoeffer leder frem til en overvejelse om ansvaret som en tredje vej mellem en almen og specifik bestemmelse af den kristne etik. Artiklen skitserer således en teologisk ansvarsetik, der samtidigt fastholder den almene og specifikke bestemmelse af etikkens grundlag. Hermed tilstræbes det dels at fastholde nogle af de væsentlige indsigter i en almen etik og dels at inddrage refleksioner over mere specifikke sider af det kristne liv.

\section{K.E. Løgstrups alment humane etik i kritisk lys}

Det centrale sted i Løgstrups forfatterskab for diskussionen om en kristen etik er kapitel V i $D E F$, der bærer overskriften "Gives der en kristelig etik?"5 Afsnittet har vakt betydelig diskussion og deler fortsat vandene. ${ }^{6}$ Tonen i afsnittet er skarp og præget af Løgstrups opgør

5. Løgstrup (1956), 122-132. For god ordens skyld skal det præciseres, at anliggendet i nærværende artikel ikke er at give en redegørelse for Løgstrups etik. Det findes andre steder. Særligt må nævnes David Bugge, Kompendium til K.E. Løstrup: Den etiske fordring. Hovedtanker og argumentationsgang (Aarhus: Forlaget Klim 2011a) og idem, Hinandens verden. Ledsager til K.E. Løgstrup: Den etiske fordring (Aarhus: Forlaget Klim 2011b). Hensigten i denne artikel er at rejse en kritisk diskussion af hans forståelse af en "kristelig etik". Derfor rettes blikket også særligt på det afsnit, hvor han rejser spørgsmålet, om der gives en sådan.

6. Denne diskussion har blandt andet udfoldet sig mellem to af de teologer, der har stået Løgstrup nærmest - Svend Andersen og Ole Jensen. Andersen har i et festskrift til sidstnævnte gjort den læsning gældende, at skønt Løgstrup forstår sin etik som overensstemmende med Luthers, overser han væsentlige sider af Kristustroens 
med sin egen samtid og fortid. ${ }^{7}$ Løgstrups anliggende er her først og fremmest, at forholdet til den radikale fordring er usynligt. Den radikale fordring har Løgstrup bestemt som den uudtalte fordring, der hverken udtales af det andet menneske (Løgstrup 1956, 31f.) eller af de sociale normer (69f.). Den er med andre ord tavs. ${ }^{8}$ Den enkelte skal selv afgøre, hvad der er bedst for den anden (56f.) Det er en fordring, der udspringer af mødet mellem mennesker, og som den enkelte med sin egen "indsigt, fantasi og forståelse" må komme overens med (32). Fordringen udspringer af den tillid, der i udgangspunktet er i ethvert møde mellem mennesker. Denne tillid betegner han som "det etiske livs grundfænomen" (27). Hvordan vi forholder os til denne fordring, er imidlertid ikke synligt. Løgstrup drager en parallel til Søren Kierkegaard i fremhævelsen af dette forholds usynlighed. (122) Løgstrup anfører ikke selv nogen henvisning til Kierkegaard på dette sted, men det er nærliggende at antage, at Løgstrup blandt andet har haft Karlighedens Gerninger i tankerne.

Løgstrups hævdelse af usynligheden af den enkeltes forhold til den radikale fordring giver god mening både ud fra spørgsmålet om, hvad man rent faktisk kan iagttage og ud fra et evangelisk teologisk standpunkt. ${ }^{9}$ Det er indlysende rigtigt, at det ikke kan påvises direkte, hvordan det enkelte menneske i sine handlinger og motiver forholder sig til den grundlæggende fordring i skaberværket. Ud fra et teologisk standpunkt ville en sådan eksplicitet også rejse problemer omkring

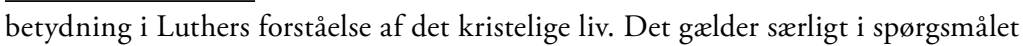
om troens forvandling af det etiske subjekt. Se Svend Andersen, "Om der gives en kristelig etik?", Kamp må der til. Engagementets brydning mellem åbenhed og tradition. Festskrift tilegnet Ole Jensen, red. Niels H. Brønnum, Erling Christiansen, Lars Paludan \& Jakob Wolf (Hadsten: Forlaget MIMER 1997), 147-156. Jensen har senere gjort gældende, at Løgstrups universelle etik grundlæggende er udtryk for "kristendommens etik", men at det specifikt kristelige intet bidrag giver til den. Se Ole Jensen, "Gives der stadig ikke en kristen etik?", Livtag med den etiske fordring, red. David Bugge \& Peter Aaboe Sørensen (Aarhus: Forlaget Klim 2007), 155-173 (163). Andersen fastholder imidlertid i samme udgivelse sin læsning, hvor han påviser Løgstrups manglende opmærksomhed på Luthers forståelse af den kristne tros forvandling af det etiske subjekt, se Andersen (2007), særligt 73-76.

7. Se Ole Jensen, Historien om K.E. Løgstrup (København: Forlaget ANIS 2007), 245f., hvor Jensen medgiver, at Løgstrup i dag formentligt ville have formuleret sig lidt mindre provokerende.

8. Bugge peger på, at Løgstrup bruger udtrykket 'uudtalt' synonymt med beskrivelsen af fordringen som 'tavs', og at dette er uheldigt grundet tvetydigheden i det første prædikat. Der skelnes i det 'uudtalte' ikke tilstrækkeligt tydeligt mellem den anonyme erfaring af fordringen i forhold til, at den ikke er konkretiseret. Bugge argumenterer derfor for fordringens tavse karakter som terminologisk mere præcis. (Bugge 2011b, 51ff.)

9. Med 'evangelisk teologisk' sigter jeg til den helt grundlæggende protestantiske indsigt, at det er troen alene, der er frelsesgrundlaget for det enkelte menneske. 
efterlevelsen af den etiske grundfordring, da det ville indebære en umiddelbar risiko for at kunne bevæge sig i retning af overfladiskhed, småborgerlighed - ja endog hykleri. Løgstrup ville her blandt andet pege på konventioner og sociale normer, som det vi må differentiere fra selve den etiske fordring (56ff.) Teologisk vil en synlighed endvidere indebære risikoen for en lovorienteret og moraliserende kristendomsforståelse. Hævdelsen af usynligheden er derfor ikke i sig selv problematisk.

At forholdet til den etiske fordring er usynligt er imidlertid en vigtig præmis for Løgstrups følgende refleksion, hvor han eksplicit rejser spørgsmålet "Gives der en kristelig etik?" (125ff.) Dette afsnit er mere problematisk. Et af de centrale anliggender i afsnittet er at argumentere for det enkelte menneskes ansvar i efterlevelsen af den etiske fordring, der netop rejser sig på grund af fordringens tavshed. Tavsheden og ansvaret for at efterleve fordringen hænger nøje sammen. Dette er i øvrigt et anliggende, han deler med Bonhoeffer, som vi vil vende tilbage til. Det mest problematiske afsnit hos Løgstrup er imidlertid det, der begynder med "Hvad enten det derfor ..." (128). Her bevæger Løgstrup sig ind på materialetiske områder så som ægteskab, børneopdragelse, straffens motivering og politisk-økonomiske retfærdighedsovervejelser. Løgstrup mener, at det kristne menneske må tage stilling til disse spørgsmål på samme vilkår som alle andre mennesker.

Her rejser det første problem sig. Tilsyneladende lader Løgstrup ude af betragtning, at der i både nytestamentlig teologi og i Luthers teologi er en skelnen mellem den etiske grundnorm og denne grundnorms forskellige udtryk. ${ }^{10} \mathrm{I}$ både Jesu etiske forkyndelse og i Luthers etik indebærer denne sondring, at der på den ene side er en etisk grundnorm, som vi kan sammenfatte i den naturlige lov eller den gyldne regel, og på den anden side en række specificeringer af denne grundnorm, som ganske vist henter deres begrundelse i denne, men som samtidig virker tilbage på og herigennem kvalificerer grundnor-

10. Se for eksempel Wolfgang Schrage, Ethik des Neuen Testaments (Göttingen: Vandenhoeck und Ruprecht 1982) og Paul Althaus, Die Ethik Martin Luthers (Gütersloh: Gütersloher Verlagshaus 1965). Denne skelnen genfinder vi dog, når Løgstrup i sit senere værk Norm og spontaneitet sondrer mellem etikkens principielle problemer, etiske begreber og de specielle etiske problemer. Se K.E. Løgstrup, Norm og spontaneitet. Etik og politik mellem teknokrati og dilettantokrati (København: Gyldendal 1972) Når Løgstrup her reflekterer over spørgsmål som for eksempel "kærlighed og seksualitet", "politik og økonomi”, "terrorbalancen” og "biologi og etik," er der reelt tale om en materialetik. Men denne er naturligvis fortsat foretaget i lyset af den fænomenologiske etik, som han lægger grunden til med Den etiske fordring, dog med den tilføjelse, at han i mellemtiden er blevet opmærksom på de såkaldte "suveræne livsytringer". Se Andersen (1995, 68ff.) og Jensen (2007, 104ff.). 
men. Der er altså en vekselvirkning mellem den etiske grundnorm og dens eksplicitte udtryk, som Løgstrup tilsyneladende lader ude af betragtning. Løgstrup anvender ganske vist et begreb om prismer, der kunne foranledige en til at tro, at der her er tale om et sådant vekselvirkningsforhold. Hos ham er det dog ikke ment sådan, at disse prismer kaster lys tilbage på fordringen, men derimod, at forholdet mellem fordringen og handlingen brydes. ${ }^{11}$

Løgstrup gør dernæst gældende, at det kristne menneske ikke af det kristne budskab kan uddrage nogen materialetik: "Det menneske, for hvem det kristne budskab er den afgørende sandhed om hans eksistens, kan ikke i det budskab hente nogle specifikke, kristelige argumenter for det ene eller andet syn på ægteskab, børneopdragelse [etc, UN]" (128). Udsagnet er problemfyldt, fordi Løgstrup her udvider sin afvisning af, at der kan udledes en specifik, kristen etik af fordringen til at gælde "det kristne budskab" som helhed. Det rejser spørgsmålet, hvad Løgstrup mener med denne betegnelse. ${ }^{12}$ Formentligt refererer han her fortsat til Jesu etiske forkyndelse, som har været hans orienteringspunkt igennem hele $D E F$. Men hvis vi tager udsagnet for pålydende, er der i disse bemærkninger en afvisning af, at der overhovedet i “det kristne budskab” kan findes etiske argumenter for stillingtagen til konkrete etiske spørgsmål. Igen må det gøres gældende, at enten glemmer Løgstrup, at det at tale om en etisk grundnorm og en række specifikke udlægninger af denne ikke udelukker hinanden, eller han tilsidesætter denne sammenhæng. Det er imidlertid ganske enkelt ikke rigtigt, at der i "det kristne budskab" ikke skulle være argumenter i forhold til specifikke etiske spørgsmål. De bibelske tekster, den kristne tradition og nyere teologisk refleksion rummer talrige eksempler på, at der ud fra "det kristne budskab" med god begrundelse kan argumenteres for en konkret stillingtagen til specifikke etiske spørgsmål. ${ }^{13}$

11. Løgstrup udpeger tre måder, hvorpå fordringen brydes gennem et prisme - relationen man indgår $\mathrm{i}$ til den anden, situationen som den anden befinder sig i, og den enkeltes natur (Andersen 2007, 67ff.; Bugge 2011b, 120ff.).

12. Det kan gøres gældende, at Løgstrup her mener det specifikke i det kristne budskab. Det gør det imidlertid ikke meget klarere, al den stund det er vanskeligt at tale om kristendom uden det, der gør kristendom til kristendom, altså det specifikke. Når Løgstrup anvender så bred en betegnelse som "det kristne budskab", er det derfor mere redeligt at medgive, at han her kunne have været mere præcis. Dertil tjener Bugges ledsagerbind, hvor han dels giver udtryk for, at dette afsnit "ikke hører til de mest stringent opbyggede i bogen" (Bugge 2011b, 123), dels angiver, at der er tale om "kristendommen" mere bredt forstået, og at en argumentation herudfra efter Løgstrups opfattelse vil føre til en forenkling af problemstillingerne (ibid., 133).

13. Blandt talrige eksempler på dette vil jeg her blot nævne The Oxford Handbook of Theological Ethics, red. Gilbert Meilaender og William Werpehowski (Oxford: 
Løgstrup fortsætter denne passage med at hævde, at det kristne menneske i stillingtagen til etiske spørgsmål må " argumentere for sin opfattelse på det ene og andet område som enhver anden - og med argumenter, der må kunne godtages af den ikke-kristne ligeså godt som af den kristne" (128). Udsagnet er problematisk, fordi det fuldstændigt tilsidesætter, at der for det kristne menneske i forholdet til Kristus, i forhold til at være del af en kristen kirke, i forhold til forkyndelsen, i forhold til sakramenternes etiske implikationer (i blandt andet Luthers dåbsteologi er der betydelige etiske implikationer) og i forhold til den teologiske tradition findes etiske implikationer, som er særegne for det kristne menneske. ${ }^{14}$ Ved at opstille en præmis om, at etikken for både det kristne menneske og den ikke-kristne skal gøres gældende med almene argumenter, reducerer Løgstrup den kristne etik til alene at være almen. Dermed mister han den del af den kristne etik, der har et særligt kendetegn, og kommer derfor også i risiko for helt at tilsidesætte den kristne tros etiske implikationer.

Problemstillingen bliver yderligere skærpet, når Løgstrup går videre og hævder, at "han [det kristne menneske, UN] må bruge sin egen fornuft, indsigt og menneskelighed for selv at komme til klarhed over spørgsmålene, ligesom han må appellere til det andet menneskes fornuft, indsigt og menneskelighed uden tanke på, om den anden er kristen eller ikke-kristen" (128) Udsagnet rummer to grundlæggende problemer. For det første synes Løgstrup i disse formuleringer at antage, at det kristne menneske er fuldstændigt upåvirket af den kristne tro og i sin etiske stillingtagen ikke i nogen henseende er enten præget eller informeret af denne overbevisning. For det andet tilsidesætter Løgstrup hele den lange kristne tradition (de bibelske tekster, den teologiske tænkning og aktuel teologisk og kirkelig refleksion) som tæt på irrelevant for det kristne menneskes etiske stillingtagen. ${ }^{15}$

Løgstrup fortsætter sin refleksion med at hævde, at det er en "uting", hvis der findes et "frimureri" mellem kristne indbyrdes i

Oxford University Press 2007), hvis hoveddele redegør for sammenhængen mellem dogmatik og etik, kilderne til moralsk erkendelse, det kristne livs strukturer, det kristne livs sfærer og en kritisk fremstilling af centrale værker indenfor teologisk etik. Denne replik til Løgstrup ligger i øvrigt tæt på den kritik, som han allerede blev mødt med et par år efter udgivelsen af $D E F$. Se N. H. Søe, "Den etiske fordring", DTT 21 (1958), 1-15 (10f.). Det er i den forbindelse også værd at bemærke, at Løgstrup selv modificerer sit standpunkt i årene derefter (se note 15). Se endvidere note 10 .

14. For en indføring i den kristne etiks liturgiske forankring, se for eksempel The Blackwell Companion to Christian Ethics, red. Stanley Hauerwas og Samuel Wells (Malden, MA/Oxford, UK/Victoria, Australia: Blackwell Publishing 2004).

15. Bugge medgiver, at et kritikpunkt som dette formentligt ikke ville have gjort nævneværdigt indtryk på Løgstrup (Bugge 2011b, 129, note 59). 
etiske og politiske spørgsmål (129). Kritisk kan det anmærkes, at et begreb som "uting" ikke er synderligt præcist, og at det derfor henstår i uklarhed, hvori problemet egentligt består. Dette problem bliver desto større, når der er solidt grundlag i både bibelske tekster og den teologiske tradition for at hævde, at det kristne liv har noget særligt ved sig. ${ }^{16}$ Det er denne side af det kristne liv, som er grundlaget for, at der er et vidnesbyrd forbundet med det kristne liv. Når Løgstrup bruger betegnelsen "frimureri" kan det heller ikke siges at fremme argumentationen, men må snarere læses som en polemisk og sarkastisk bemærkning til forestillingen om det kristne liv som noget særligt.

I de følgende passager argumenterer Løgstrup for sit standpunkt. Ifølge Løgstrup har fordringen i Jesu forkyndelse alene den andens gavn for øje. Når den enkelte bliver stillet over for fordringen, må vedkommende sætte sine "egne velforståede interesser" til side (129). Evangeliet kan derfor ifølge Løgstrup ikke bruges som argument (ibid.). Løgstrup gør dernæst gældende, at en henvisning til kristendommen ville indebære, at den enkeltes "forstand, indsigt og kærlighed" dermed sættes ud af spil (130). Med andre ord - for at den etiske fordring fremstår med sin radikalitet, er det afgørende, at det er den enkeltes "indsigt, fantasi og forståelse" (32), der i den konkrete situation afgør, hvad der er den anden til gavn. Hvis denne forståelse opgives, er der en risiko for, at kristendommen reduceres til ideologi, og at næsten bliver til en genstand for en bestemt sag, som man ønsker fremmet (130). Problemet er ifølge Løgstrup, at man får en tendens til at gøre ordene, handlingerne, standpunkterne og løsningerne til det radikale fremfor at lade den tavse fordring være det radikale (130f.). Ved en forskydning i retning af ordene og standpunkterne, risikerer man at miste optagetheden af det andet menneske, som fordringen retter sig mod (131).

Når Løgstrup så markant afviser en kristelig etik i denne passage i $D E F$ hænger det altså tæt sammen med hans understregning af den etiske fordring som radikal. Det er der gode grunde til. Problemet hos Løgstrup er, at han i flere af sine formuleringer dels bliver tvetydig og dels går for vidt. I flere af sine formuleringer er det ikke helt klart, hvad han faktisk mener, når han for eksempel skriver om "det

16. Se for eksempel note 10 og 13. Der ud over kan blandt andet henvises til Richard B. Hays, The Moral Vision of the New Testament: Community, Cross, New Creation. A Contemporary Introduction to New Testament Ethics (Edinburgh: T\&T Clark 1997) for en indføring i en særlig nytestamentlig etik. I forhold til den teologiske tradition se blandt andet J. Philip Wogaman, Christian Ethics: A Historical Introduction (London: SPCK 1994) og Readings in Christian Ethics. A Historical Sourcebook, red. J. Philip Wogaman \& Douglas M. Strong (Louisville, KY: Westminster John Knox Press 1996). 
kristne budskab" (128), eller at "kristendommen" ikke giver grundlag for en "bedreviden" (129f.). Han går for vidt, når han så markant afviser, at der er en sammenhæng mellem det kristne budskab og etikken, til trods for, at han rent faktisk indleder $D E F$ med kirkens forkyndelse og herudfra hævder, at den må svare til noget i vores tilværelse for at være vedkommende (9). Han går i dette afsnit også for vidt i lyset af sine senere indrømmelser, hvor han delvist medgiver, at der kan tales om en kristen etik. ${ }^{17}$ Selv om Løgstrup altså er meget markant i sin afvisning af en kristen etik i kapitel V i $D E F$, kan vi således se, at selv Løgstrup ikke helt kan opgive den. Derfor vender vi os nu mod en anden teologisk etiker, hvor det specifikt kristelige er mere fremhævet.

\section{Dietrich Bonhoeffers etik mellem radikalitet og kompromis}

Hos Bonhoeffer finder vi en forståelse af den kristne etik, der samtidigt fastholder den almene og specifikke side. Bonhoeffer bestemmer denne dobbelthed med udgangspunkt i kristologien, nærmere bestemt inkarnationen og den heri indeholdte forsoning af verden med Gud. For Bonhoeffer indebærer dette en forståelse af virkeligheden, der gør det umuligt at adskille verdens og Guds virkelighed uden at adskille Kristusvirkeligheden. Dette er et centralt anliggende for Bonhoeffer i indledningsafsnittet "Christus, die Wirklichkeit und

17. Det er i den forbindelse værd at være opmærksom på, at selv om Ole Jensen i flere udgivelser støtter Løgstrup i afvisningen af en kristen etik, så medgiver Jensen, at der ikke er nogen uoverensstemmelse mellem Løgstrups skabelsesetik og kristendommen. Han gør endog gældende, at "kristendommens etik er denne etik, de falder sammen”. Han gør videre også opmærksom på, at Løgstrup sidst i sit liv kan tale om en "kristen moral" og den etik, som er forbundet med "kristendommen" (Jensen 2007, 246). Hos Løgstrup selv finder vi forskellige modificeringer af hans afvisning af en kristen materialetik allerede i 1961, hvor han diskuterer med flere af sine kritikere (K.E. Løgstrup, Kunst og etik (København: Gyldendal 1961), 212218). Men også i første halvdel af firserne medgiver han i posthumt udgivne skrifter, at der kan tales om en kristen moral (K.E. Løgstrup, System og symbol. Essays (København: Gyldendal 1982), 124f.), og at kristendom og etik er forbundne, Løgstrup 1984, 59f. Hvis disse sene tekster læses i lyset af Løgstrups tidlige forstålse af sig selv som kristen etiker og hans fremhævelse af åbenbaringens nødvendighed for "den endegyldige etiske sandhed" (se Kees van Kooten Niekerk, "Vejen til den etiske fordring", Livtag med den etiske fordring, red. David Bugge og Peter Aaboe Sørensen (Aarhus: Forlaget Klim 2007), 9-46 (11)) rejser det spørgsmålet, om Den etiske fordring grundlæggende er at læse som Løgstrups udfoldelse af den almene side af en kristen etik, men at dette netop som sådan er uløseligt forbundet med et særligt (og dermed specifikt) udgangspunkt. 
das Gute. Christus, Kirche und Welt" fra hans Ethik (DBW 6). ${ }^{18}$ Det indebærer dels, at der hos Bonhoeffer er en bekræftelse af den kristne etiks almene side. Bonhoeffer understreger således vigtigheden af at forstå mennesket som et udelbart hele i fællesskab med andre mennesker og skabninger (38), ligesom han gør gældende, at der ikke er nogen kristelig virkelighed adskilt fra verdens virkelighed (47). Dels indebærer det, at han lige så markant kan fremhæve etikkens specifikke bestemmelse, idet det ikke giver mening at tale om verdens virkelighed adskilt fra Kristi virkelighed. Ifølge Bonhoeffer er det en tom abstraktion at tale om verden uafhængigt af Kristus: "Ohne Christus von der Welt zu sprechen, ist leere Abstraktion. Die Welt steht in Beziehung auf Christus, ob sie es weiß oder nicht" (54). For Bonhoeffer er der altså tale om en samtidig bekræftelse af verden og at denne bekræftelse ikke lader sig løsrive fra Kristus, uden at den ender i meningsløshed. Denne dobbelthed er afgørende for hans forståelse af den kristne etik som både almen og specifik. ${ }^{19}$

For at forstå Bonhoeffers etik er det imidlertid væsentligt at være opmærksom på, at han har et kritisk syn på etik. Allerede i sine tidlige skrifter udtrykker han et forbehold overfor kristen etik. Det gælder for eksempel foredraget "Grundfragen einer christlichen Ethik", som han holdt i februar 1929 for menigheden i Barcelona, hvor han havde et vikariat som præst. ${ }^{20}$ Bonhoeffer opfatter det som udsigtsløst at forsøge at opstille kristeligt almene (christlich allgemeingültige) normer i forhold til tidens etiske spørgsmål. Opgaven må snarere være at belyse de etiske spørgsmål ud fra kristelige grundideer og her ud fra at tage del i disse (DBW 10, 323). Bonhoeffer fører imidlertid denne kritik videre, idet han gør gældende, at etikken bærer en kim i sig til sin egen guddommeliggørelse. Religionen og moralen kan dermed komme til at stå i vejen for, at Gud kommer til mennesket. Det kristne budskab er derfor i den forstand grundlæggende areligiøst og amoralsk (315). Bonhoeffer kan derfor også med henvisning til

18. Dietrich Bonhoeffer, Ethik, Dietrich Bonhoeffer Werke (DBW), bd. 6, red. Ilse Tödt, Heinz Eduard Tödt, Ernst Feil \& Clifford Green (Gütersloh: Chr. Kaiser Verlag/Gütersloher Verlagshaus ${ }^{2} 1998$ (1992)), 31-61.

19. Denne dobbelthed og samtidig enhed mellem disse to sider har jeg analyseret i en række udgivelser. I denne forbindelse vil jeg blot henvise til min disputats, hvor jeg giver en samlet kritisk redegørelse for flere af disse studier. Se Ulrik Becker Nissen, Between Universality and Specificity. A Study of Christian Social Ethics with Particular Emphasis on Dietrich Bonhoeffer's Ethics (Aarhus Universitet: Upubliceret disputats 2014).

20. Dietrich Bonhoeffer, "Grundfragen einer christlichen Ethik. 8.2.1929", Barcelona, Berlin, Amerika. 1928-1931. DBW 10, red. Reinhart Staats, Hans Christoph von Hase, Holger Roggelin \& Matthias Wünsche (Gütersloh: Chr. Kaiser Verlag/ Gütersloher Verlagshaus ${ }^{2} 2005$ (1992)), 323-345. 
Friederich Nietzsche sige, at det kristne budskab står hinsides godt og ondt: "Die christliche Botschaft steht jenseits von Gut und Böse " (327). Bonhoeffer kommer meget tæt på formuleringer, som minder om dem, vi finder hos Løgstrup, når han tilsyneladende slutter, at kristendom og etik overhovedet ikke har noget med hinanden at gøre (327).

Samme etikkritiske standpunkt kan vi genfinde i hans Ethik fra begyndelsen af 1940'erne, når han blandt andet skriver, at skønt man kan synes, at det må være målet for al etisk besindelse at nå frem til en viden om godt og ondt, så er den kristne etiks primære opgave at ophæve denne viden: "Das Wissen um Gut und Böse scheint das Ziel aller ethischen Besinnung zu sein. Die christliche Ethik hat ihre erste Aufgabe darin, dieses Wissen aufzuheben" (DBW 6, 301). Denne opgave er særegen for den kristne etik, hvorfor Bonhoeffer kan tale om netop den kristne etik som "Kritik aller Ethik" (ibid.). I både Barcelonaforedraget og i dette afsnit i Ethik (301ff.) knytter Bonhoeffer sin etikkritik til syndefaldet. Teologisk set består syndefaldet netop i dette, at mennesket kommer til erkendelse af godt og ondt. Syndefaldet giver mennesket en etisk bevidsthed, hvorved det samtidigt bevæger sig væk fra det umiddelbare forhold til Guds vilje. Etikkens opgave bliver derfor også at reflektere over forsoningen som grundlaget for det kristne liv og hvad denne forsoning indebærer (DBW 6, 311).

Bonhoeffer bliver således ikke stående ved den etikkritiske position. For ham er det klart, at en kristen teologi har etiske implikationer. Derfor er store dele af hans forfatterskab præget af en refleksion over disse etiske implikationer. Snarere end en teologisk etik kan det imidlertid give god mening at tale om en etisk teologi hos Bonhoeffer. ${ }^{21}$ Dette viser sig allerede i nævnte Barcelonaforedrag, hvor han reflekterer over tidens etiske spørgsmål i lyset af kristelige grundidéer (DBW 10, 323). Denne grundbestemmelse af etikken kan vi følge hele vejen op igennem hans forfatterskab. Forståelsen indebærer, at han bevæger sig bort fra de traditionelle etiske kategorier og er bevidst om ikke at placere sig indenfor enten pligt-, konsekvens- eller dydsetikken (DBW 6, 31f.). Disse etiske tilgange har hver især noget rigtigt ved sig, men de rummer samtidigt også så mange problemer, at vi er nødt til at tænke etik bredere. Hvor de nævnte etiske tilgange overvejende er filosofiske bestemmelser, kan det samme imidlertid også siges om mere teologiske grundbestemmelser af etikken. Grundforståelserne er her ikke helt så afgrænsede, men alligevel kan vi skelne mellem for eksempel en skabelsesteologisk etik, en efterfølgelsesetik, en ek-

21. Se for eksempel James Burtness, Shaping the Future: The Ethics of Dietrich Bonhoeffer (Philadelphia: Fortress Press 1985). 
klesiologisk etik og en bibelsk etik. Disse forskellige tilgange til en teologisk etik vil indebære alternative svar på de etiske udfordringer. For Bonhoeffer er det imidlertid karakteristisk, at han også i forhold til disse bestemmelser bevæger sig ud over en traditionel afgrænsning. Det viser sig blandt andet $\mathrm{i}$ hans bestræbelse på grundlæggende at bestemme den teologiske etik mellem radikalitet og kompromis, som han særligt udfolder i sin Ethik i afsnittet om "Die letzten und die vorletzten Dinge" (137ff.).

For Bonhoeffer er det afgørende, at både den radikale bestemmelse af etikken og kompromiset er ekstreme løsninger. Som sådan ender de også med at adskille en bestemmelse af den teologiske etik, som snarere burde være holdt sammen. Den radikale etik forstår Bonhoeffer som den position, der udelukkende har "das Letzte" for øje (144). Dette "Letzte" bestemmer han tidligere i afsnittet som retfærdiggørelsen af nåde alene (137). Når der ensidigt fokuseres på "das Letzte", risikerer vi at ende med en forståelse, hvor Kristus anskues i modsætningsforhold, sågar fjendskab, i forhold til "das Vorletzte". Kristus opfattes her som "der Zestörer und Feind alles Vorletzten und alles Vorletzte ist Feindschaft gegen Christus" (144). Den radikale forståelse bliver derfor også kendetegnet ved et had mod det bestående. Snarere end at være kendetegnet af en kærlighed til verden, ender denne forståelse med en foragt og bitterhed over for verden og medmennesket. Kirken bevæger sig i denne forståelse bort fra at være et åbent fællesskab, der tjener verden, til at være bestemt af et snævert ideal om kirken som et særligt meningsfællesskab (147). ${ }^{22}$ Kompromisset er derimod kendetegnet ved, at "das Letzte" adskilles fra "das Vorletzte", som derved ikke anfægtes af dette. "Das Vorletzte" får dermed mulighed for at bestå helt uafhængigt og afsondret fra "das Letzte", som til gengæld for sin del bliver bestemt som helt igennem hinsidigt (145). Derved bliver kompromisset også kendetegnet ved et had over for retfærdiggørelsen af synderen ved nåde alene. Verden og dets liv må ifølge denne forståelse værnes mod nådens indbrud (Einbruch) i dets område (Bereich). Nåden har ifølge denne forståelse ikke noget at gøre med livet i verden. Alene at rejse spørgsmålet om Guds ords autoritet i forhold til verden opfattes som udtryk for radikalitet (147f.). ${ }^{23}$

22. Der er træk i denne karakteristik af det radikale, hvor det får lighed med den forståelse af kristen etik, som Løgstrup gør op med. Det er blandt andet tilfældet, når han gør op med, at kristendommen skulle kunne give grundlag for en "politisk eller etisk bedreviden” (1956, 129). Bonhoeffer og Løgstrup deler derfor for så vidt en afstandtagen til det, som Bonhoeffer her betegner som radikalisme.

23. Hvor Løgstrup og Bonhoeffer deler en kritik af radikalismen, kan man imidlertid rejse spørgsmålet, om det også er tilfældet i forholdet til kompromiset, som 
De to meget forskellige og hver for sig ekstreme løsninger ender derfor også med to helt fundamentalt forskellige forståelser:

Der Radikalismus haßt die Zeit, der Kompromiß haßt die Ewigkeit; der Radikalismus haßt die Geduld, der Kompromiß haßt die Entscheidung, der Radikalismus haßt die Klugheit, der Kompromiß haßt die Einfalt.

Der Radikalismus haßt das Maß, der Kompromiß haßt das Unermeßliche. Der Radikalismus haßt das Wirkliche, der Kompromiß haßt das Wort (148).

Det afgørende problem i denne modstilling af radikaliteten og kompromiset er, at de dermed bliver, hvad Bonhoeffer kalder ualvorlige. De tager ikke alvorligt, at Guds og verdens virkelighed er ét i Kristi virkelighed: "Weder die Idee eines reinen Christentums an sich noch die Idee des Menschen, wie er an sich ist, ist ernst; ernst ist allein die Wirklichkeit Gottes und Wirklichkeit des Menschen, die in Jesus Christus eins geworden ist" (146). For Bonhoeffer kan der derfor ikke tales om en kristendom i sig selv, uafhængigt af verden. Lige så lidt som der kan tales om mennesket i sig selv, der udelukker forholdet til Gud (146). Det afgørende for Bonhoeffer er derfor også, at vi sammenholder disse modsætninger, hvis helt centrale forening vi finder i Kristus. ${ }^{24}$ Med denne dobbelte bestemmelse af den kristne etik bliver Bonhoeffers etik dermed samtidigt almen og specifik. Han får således formuleret en forståelse af etikkens grundlag, der fastholder, hvad Løgstrup ville betegne som alment humant og samtidigt inddrager han en specifik bestemmelse afledt af kristologien.

\section{Ansvaret som en tredje vej for kristen etik}

Sameksistensen af det almene og specifikke genfinder vi i ansvarsbegrebet. Det er i øvrigt et område, hvor Løgstrup og Bonhoeffer har bemærkelsesværdigt lignende opfattelser. Ansvarsbegrebet åbner dermed op for et område, hvor Løgstrup og Bonhoeffer tilsyneladende kan bringes i en frugtbar samtale med hinanden.

Bonhoeffer forstår det. Når Løgstrup så skarpt afviser, at der i "det kristne budskab" $(1956,128)$ skulle kunne hentes nogen form for argumenter i specifikke etiske spørgsmål, samtidigt med, at han betoner, at det kristne menneske må tage stilling “... på ganske de samme vilkår som enhver anden" (ibid.), synes der at være træk, der nærmer sig, hvad Bonhoeffer ville betegne som en kompromisposition.

24. Jeg har i nævnte disputats argumenteret for, at Bonhoeffer her lægger sig op ad en luthersk forståelse af communicatio idiomatum, således at han i lyset af tanken om egenskabernes udveksling samtidigt kan tale bekræftende om Guds og verdens virkelighed, idet begge er forenet i Kristusvirkeligheden. Se Nissen (2014), 60-67. 
Når ansvarsbegrebet rummer mulighed for en tredje forståelse af den teologiske etik mellem det almene og specifikke skyldes det, at der i lyset af denne tilgang til etikken dels ikke på forhånd er fastlagte retningslinjer, men at det er i det konkrete gensvar, at det etisk rette må bestemmes, og dels at dette gensvar åbner op for spørgsmålet, hvorfra dette gensvar henter sin prægning. Helt basalt er ansvaret et gensvar. På dansk finder vi det i selve ordet ansvar, der etymologisk er afledt af at 'gen-svare'. Ansvaret er altså udtryk for, at vi gensvarer eller responderer på noget. Ansvaret kan vise sig i en række forskellige livssituationer, opgaver og udfordringer. Fælles for dem alle er dog, at der er tale om en form for respons, som giver anledning til ansvaret. Vi finder den samme betydning i det engelske response og responsibility, der begge er afledt af det latinske respondeo. På tysk finder vi det også i ver-antwortung, som ligger meget tæt op ad det danske at 'gensvare'. Gensvaret indgår altså i en form for dialog, hvor vi svarer igen ved at påtage os det ansvar, der er blevet lagt hen til os. ${ }^{25}$

Vi kan pege på mange vigtige implikationer af denne responsive forståelse af ansvar. Men en af de afgørende bestemmelser er, at ansvaret er et relationelt begreb. Det er et etisk begreb, der fremhæver, at vi lever i indbyrdes relationer til hinanden, og at der herudfra rejser sig et ansvar. Ansvarlig er vi altid over for nogen eller noget. Løgstrup formulerer det således: "Ansvarlig bliver man af, at noget kommer til at bero på een." 26

I Løgstrups etik er ansvarsbegrebet gennemgående. Selve begrebet "ansvar" nævnes gentagne gange i DEF. Vi møder det allerede i indledningsafsnittet, når Løgstrup taler om fordringen som det, der giver et ansvar for den anden, som dog aldrig kan bestå i at overtage hans eget ansvar (Løgstrup 1956, 39). Ligeledes møder vi det centrale steder, som når han for eksempel skal bestemme det etiske livs grundfænomen. Dette fænomen differentierer han fra, hvad han kalder den "frit opfundne og spontane velgerning" (66). Denne forudsætter en uproblematiseret respekt for hinandens selvstændighed og uafhængighed. Det er imidlertid en utilstrækkelig bestemmelse, da det ikke i fornøden grad har blik for det magtforhold, der er givet med den etiske afgørelse. Netop erkendelsen af denne magt og at vi dermed er spærret inde i afgørelsen, om vi vil bruge magten til den andens eller til vort eget bedste, giver grundlaget for ansvaret (ibid.). Ansvarsbegrebet bruges med andre ord til at sammenfatte den afgørelse, som den etiske fordring stiller os overfor.

25. Se hertil i øvrigt Ulrik Nissen, Ansvar. Tænkepauser (Aarhus: Aarhus Universitetsforlag, under udgivelse)

26. K.E. Løgstrup, Etiske begreber og problemer (Aarhus: Forlaget Klim 2014), 56. 
Derfor kan Løgstrup også sige, at usynligheden i forholdet til den etiske fordring stiller os i det ansvar, som kun kan være vores eget. Vi kan ikke komme til fuld vished om, hvad der er det rette at gøre, og er derfor henvist til vores eget ansvar i denne afgørelse. Den enkelte kan aldrig "have en fuldkommen sikkerhed for at have handlet ret og rigtigt. Så vist som fordringen brydes af vor indsigt og menneskelighed, handler vi på eget ansvar" (125). Den centrale betydning af ansvarsbegrebet bekræftes endvidere af, at dette er et af de begreber, som Løgstrup særligt drøfter i Etiske begreber og problemer. Han knytter også her ansvarsbegrebet tæt til magten: "den ansvarlige har magt over den, for hvem han har ansvar. Blot består det ansvarlige forhold $i$, at med denne magt skal den ansvarlige tjene den, for hvem han har ansvar" (57). Når Løgstrup reflekterer over ansvarsbegrebets oprindelse efter første verdenskrig henviser han til en erkendelse, der var nået om menneskenes indbyrdes afhængighed: "(K)arakteristisk for vor tilværelse er det, at vi er indbyrdes afhængige af hinanden, og at afhængighed går så dybt, at uden den ville vor tilværelse slet ikke være menneskelig" (58). Løgstrup formulerer med andre ord oprindelsen af ansvarsbegrebet som sammenfaldende med en erkendelse af den menneskelige indbyrdes afhængighed, der har lighed med hans forståelse af menneskelivets grundvilkår, som ligger til grund for den etiske fordring.

Hvor læsningen af Løgstrups etik ikke har været fokuseret på hans ansvarsbegreb, ${ }^{27}$ er situationen ganske anderledes for Bonhoeffer. Der er et meget stort antal artikler og monografier, der analyserer hans etik med ansvarsbegrebet som optik. ${ }^{28}$ Det er der god grund til. I hans Ethik dedikerer han et større afsnit til ansvarsbegrebet, "Die Geschichte und das Gute [2. Fassung]" (DBW 6, 245-300). Et af de punkter, hvor Bonhoeffer minder om Løgstrup, er i fremhævelsen af uvisheden i den etiske afgørelse. Ligesom Løgstrup understreger Bonhoeffer, at det er en præmis for ansvaret, at det ikke på forhånd

27. Der har så vidt denne artikels forfatter er orienteret, ikke været nogle sammenhængende og større undersøgelser af Løgstrups ansvarsbegreb og forsøg på at læse ham som ansvarsetiker. Jensens indføring i Løgstrup nævner eksempelvis ikke ansvarsbegrebet overhovedet i bogens sagregister (Jensen 2007) I Livtag med den etiske fordring finder vi heller ikke bidrag, der særskilt drøfter dette begreb, Bugge og Sørensen (2007). I ledsagerbindet til DEF kommenterer Bugge ofte på ansvarsbegrebet, men det bliver ikke drøftet med et selvstændigt afsnit (Bugge 2011b).

28. Jeg vil her blot nøjes med at henvise til Gunter M. Prüller-Jagenteufel, Befreit zur Verantwortung: Sünde und Versöhnung in der Ethik Dietrich Bonhoeffers (Münster: LIT Verlag 2004). Se i øvrigt også Ulrik Becker Nissen, "Responding to Human Reality. Responsibility and Responsiveness in Bonhoeffer's Ethics", Being Human, Becoming Human: Dietrich Bonhoeffer and Social Thought, red. Jens Zimmerman \& Brian Gregor (Eugene, OR: Wipf and Stock 2010), 203-225. 
er givet, hvad der er det etisk rette at gøre (220f.; 231f.). Bonhoeffer deler endvidere lighed med Løgstrup i sin fremhævelse af etikken som bestemt i den konkrete situation. Det er den konkrete afgørelse stillet overfor det konkrete etiske spørgsmål, der danner grundlag for ansvaret (220f.; 245f.). Ligesom Løgstrup henviser til det etiske livs grundfænomen, når han skal bestemme den etiske fordrings grundlag, taler også Bonhoeffer om det etiske fænomen (37; 368f.).

På et afgørende punkt adskiller Løgstrup og Bonhoeffer sig imidlertid. Det er i spørgsmålet om Kristi betydning for ansvaret. Dette spiller tilsyneladende ikke nogen fremtrædende rolle hos Løgstrup (hvis vi da ser bort fra, at han ønsker at bestemme Jesu etiske forkyndelse alment humant). For Bonhoeffer spiller det derimod en helt afgørende rolle, idet Kristus er indbegrebet af, hvad det vil sige at leve et liv i ansvar. Bonhoeffer tager sit udgangspunkt i, at spørgsmålet om det gode er givet med livet selv. (245) Samtidigt tager han Jesu udsagn alvorligt, når Jesus siger om sig selv, at han er livet. (Joh 14,6) Det indebærer for Bonhoeffer, at hverken den filosofiske eller teologiske tænkning kan se bort fra denne bestemmelse (DBW 6, 248f). At Jesus er selve livet indebærer endvidere, at livet finder sin bekræftelse i Kristus: "Gut ist das Leben als das was es in Wirklichkeit, das heißt in seinem Ursprung, seinem Wesen und seinem Ziel ist, also Leben im Sinn des Wortes: Christus ist mein Leben" (252). At tale om mennesket i sig selv er derfor en tom abstraktion. I kraft af inkarnationen er mennesket elsket, dømt og forsonet med Gud i Kristus (253). Livet som helhed er derfor et gensvar på Guds ord til os i Kristus. Fordi det er et ord, der omfatter hele livet, kan svaret også kun omhandle hele livet (ibid.). Dette gensvar af livet som helhed forstår Bonhoeffer som ansvar.

Dieses Leben als Antwort auf das Leben Jesu Christi (als Ja und Nein über unser Leben) nennen wir "Verantwortung". In diesem Begriff der Verantwortung ist die zusammengefaßte Ganzheit und Einheit der Antwort auf die uns in Jesus Christus gegebene Wirklichkeit gemeint (...) Verantwortung bedeutet daher, daß die Ganzheit des Lebens eingesetzt wird ... (DBW 6, 254).

Med denne bestemmelse af gensvaret på forsoningen i Kristus som ansvarets grundlag giver Bonhoeffer ansvarsbegrebet en markant Kristusbestemmelse, som vi ikke finder hos Løgstrup. Bonhoeffer kan derfor også sige, at ansvar kan vi kun tale om i bekendelsen til Kristus: "Verantwortung gibt es nur im Bekenntnis zu Jesus Christus mit Wort und Leben" (256). 
Løgstrup og Bonhoeffer er således enige om en almen bestemmelse af ansvarsbegrebet. De deler opfattelsen, at ansvarsbegrebet er tæt forbundet med menneskelivet som sådan. Men de adskiller sig derved, at Bonhoeffer hævder, at vi først kender livet i lyset af Kristi ord om sig selv, at han er livet. De deler altså en almen bestemmelse af ansvarsbegrebet, men samtidig vil Bonhoeffer hævde, at der må siges mere end den rent alment humane bestemmelse. Bonhoeffers bidrag til ansvarsbegrebet kan i det lys siges at placere det som en tredje vej mellem en almen og specifik bestemmelse. For Bonhoeffer er det etiske gensvar ganske vist frit, men det kristne menneske er i dette gensvar kaldet til at være Kristus for den anden og i dette gensvar derfor at bære vidnesbyrd om Kristus. ${ }^{29}$ I dette Kristusformede gensvar bliver der hos Bonhoeffer således en tæt sammenhæng mellem omsorgen for næsten, Kristustroen og -bekendelsen samt kirken som det sted, hvor denne Kristusformation af det kristne menneske finder sted. ${ }^{30}$

29. Se hertil for eksempel Nissen (2014), 90-102.

30. Se for eksempel afsnittet "Ethik als Gestaltung” (DBW 6, 62ff. (særligt 80-90)). 